Gut, 1975, 16, 543-54

\title{
Regional differences in oxalate absorption by rat intestine: Evidence for excessive absorption by the colon in steatorrhoea
}

\author{
D. R. SAUNDERS'1, J. SILlERY, AND G. B. MCDONALD
}

From the Division of Gastroenterology, Department of Medicine, University of Washington, Seattle, Washington, USA

SUMMARY Clinical studies suggest that steatorrhoea can be associated with excessive absorption of dietary oxalate. We examined the influence of bile salts, $\mathrm{Ca}^{++}$, and long-chain fatty acid on the absorption of oxalate and water by rat intestine in vivo. Absorption was measured under steady-state conditions during single-pass infusions. Each intestinal segment served as its own control.

In jejunum, $10 \mathrm{mM}$ taurocholate, the principal salt in rat bile, depressed absorption of oxalate and water. Absorption was not depressed further by $\mathrm{Ca}^{++}$or linoleic acid.

In ileum, $10 \mathrm{mM}$ taurocholate did not inhibit absorption. Linoleic acid, $2 \mathrm{mM}$, depressed absorption of both oxalate and water.

In colon, $10 \mathrm{mM}$ taurocholate decreased absorption. Net water transport was depressed further when linoleic acid was added to the infusion, but oxalate absorption was enhanced. $\mathrm{Ca}^{++}$negated these effects of linoleic acid.

It is concluded that long-chain fatty acids may enhance the absorption of oxalate from the rat colon. This observation may be relevant to understanding hyperoxaluria in patients with steatorrhoea.

Dietary oxalate is sparingly absorbed from the normal human intestinal tract (Archer, Dormer, Scowen, and Watts, 1957). It is absorbed more avidly, however, in some intestinal disorders. When large amounts of dietary oxalate are subsequently excreted in the urine, renal stones of calcium oxalate may be formed (Chadwick, Modha, and Dowling, 1973; Stauffer, Humphreys, and Weir, 1973; Earnest, Johnson, Williams, and Admirand, 1974).

The first descriptions of 'enteric hyperoxaluria' involved patients with ileal dysfunction (Dowling, Rose, and Sutor, 1971; Admirand, Earnest, and Williams, 1971; Smith, Fromm, and Hofmann, 1972). Later, patients with small bowel bypass operations (Dickstein and Frame, 1973; O'Leary, Thomas, and Woodward, 1974), pancreatic insufficiency (Stauffer, Stewart, and Bertrand, 1974), and coeliac sprue (McDonald, Earnest and, Admirand, 1975) were found to have hyperoxaluria. Malabsorption of fat appears to underlie the

${ }^{1}$ Correspondence to: $\operatorname{Dr} \mathbf{R}$. Saunders, MD, Department of Medicine RG-20, University of Washington, Seattle, Washington 98195

Received for publication 30 April 1975. excessive absorption of dietary oxalate. Changes in the luminal milieu of the intestine, then, and not alterations in absorptive cells seem to lead to enhanced oxalate absorption.

Little is known about intestinal oxalate absorption under normal conditions. Binder has described an energy-independent, unsaturable process for oxalate transport, which was demonstrable in everted sacs of rat duodenum, jejunum, ileum, and colon (Binder, 1974). The concentration of luminal oxalate, therefore, is a determinant of the rate of oxalate absorption. What factors control the concentration of luminal oxalate? Calcium depresses the solubility of oxalate in vitro; long-chain fatty acid forms insoluble salts with calcium, thereby improving the solubility of oxalate in such a mixture (Binder, 1974). We examined the effects of bile salts, calcium, and fatty acid on oxalate absorption in rat intestine in vivo in the hope of elucidating the pathogenesis of enteric hyperoxaluria.

\section{Methods}

MATERIALS

Taurocholate was synthesized according to Norman 
(Norman, 1955). The product contained a trace of taurine: its $[\alpha]_{D^{23}}$ was 21.9 (c $=5$ in water); reported, $21 \cdot 7 \pm 0.3$ (Norman, 1955).

Linoleic acid, $99 \%$ pure, a product of the Hormel Institute, was pure as determined by thin-layer chromatography.

[U-14 C] Oxalic acid (Amersham-Searle Corp) and oxalic acid (Sigma Chemical Co) were dissolved in 95\% ethanol; chloroform was added to incipient cloudiness. The crystalline product was recrystallized from ethanol-chloroform; its uncorrected melting point was $101-103^{\circ} \mathrm{C}$ (reported, $101-102^{\circ} \mathrm{C}$ ); its specific activity was $24.7 \mu \mathrm{c}$ per mMole.

$\left[1,2-{ }^{3} \mathrm{H}\right]$ Polyethylene glycol (New England Nuclear Corp) was used without further purification.

These isotopes were measured in a toluene-based mixture (Carter and Van Dyke, 1971) with a Beckman liquid scintillation counter; ${ }^{14} \mathrm{C}$-toluene and ${ }^{3} \mathrm{H}$ toluene were used as internal standards.

\section{ANIMALS}

Male Sprague-Dawley rats, $250-300 \mathrm{~g}$, starved overnight, were injected subcutaneously with sodium pentobarbital each hour. Thirty minutes after the initial injection, surgical anaesthesia was induced with halothane; body temperature was maintained at 36 to $38^{\circ} \mathrm{C}$.

Jejunal segments, $15-25 \mathrm{~cm}$ in length, were created in the proximal $50 \mathrm{~cm}$ of the small intestine. Ileal segments extended $15-25 \mathrm{~cm}$ orally from a point $5 \mathrm{~cm}$ from the ileocaecal junction. (The rat's small intestine is about $100 \mathrm{~cm}$ in length.) After the proximal catheter had been implanted the segment was washed with control infusate (see below) for 15 minutes at $0.5 \mathrm{ml}$ per minute (Gilson Minipuls peristaltic pump) before the tip of a distal polyvinyl catheter (ID $3 \mathrm{~mm}$, length $50 \mathrm{~mm}$ ) was inserted. The abdominal incision was closed with skin clips. The control buffer was continuously infused for the next hour. After an equilibration period of 30 minutes, six five-minute samples of the intestinal effluent were obtained. A test infusate was then substituted. Following another equilibration period of 30 minutes, six five-minute samples were obtained. A period of 30 minutes was sufficient for $99.3 \%$ of an injected bolus of phenol red to be completely recovered in the intestinal effluent.

Colonic segments consisted of the large intestine distal to the caecum. A polyvinyl catheter (ID $5 \mathrm{~mm}$ ) was inserted into the anus. The colon was cleansed by infusing buffer at $0.75 \mathrm{ml}$ per minute in a retrograde direction so that faecal masses could be delivered through an incision in the proximal ascending colon. Thereafter the colon was infused at $0.75 \mathrm{ml}$ per minute in an isoperistaltic direction. Equilibration periods were of $\mathbf{4 5}$ minutes' duration because this amount of time was necessary to recover $99.2 \%$ of an injected bolus of ${ }^{3} \mathrm{H}$-polyethylene glycol. Six five-minute samples were obtained after each equilibration period.

Rats were killed by inhaling halothane. The intestinal segment was removed and was dried for 18 hours in an oven at $90^{\circ} \mathrm{C}$.

\section{INFUSATES}

The buffer for infusing jejunal segments consisted of $\mathrm{NaHCO}_{3}, 10 \mathrm{mMolar} ; \mathrm{KCl}, 6 \mathrm{mMolar} ; \mathrm{NaCl}$, 131 mMolar; [14 C]-oxalic acid, 0.22 mMolar; $\left[{ }^{3} \mathrm{H}\right]$-polyethylene glycol, $0.5 \mathrm{mMolar}$; gas phase, $5 \% \mathrm{CO}_{2}$ in $\mathrm{O}_{2} ; \mathrm{pH}, 7 \cdot 1-7 \cdot 2$.

The buffer for infusing colonic or ileal segments consisted of $\mathrm{NaHCO}_{3}, 40$ mMolar; $\mathrm{KCl}, 8 \mathrm{mMolar}$; $\mathrm{NaCl}, 75$ mMolar; $\left[{ }^{14} \mathrm{C}\right]$-oxalic acid, $0.22 \mathrm{mMolar}$; $\left[{ }^{3} \mathrm{H}\right]$-polyethylene glycol, $0.5 \mathrm{mMolar}$; gas phase, $5 \% \mathrm{CO}_{2}$ in $\mathrm{O}_{2} ; \mathrm{pH}, 7 \cdot 5-7 \cdot 7$.

Oxalate, $\mathbf{0 . 2}$ mMolar, was chosen because this concentration may obtain in the human gastrointestinal tract. Man ingests about 1 mMole of oxalate daily (Zarembski and Hodgkinson, 1962) which may be dispersed in about 51 of luminal contents.

Sodium taurocholate was added at the expense of $\mathrm{NaCl}$ in the test infusions.

\section{CALCULATIONS}

The amount of water absorbed by an intestinal segment was obtained from the differences between pump input and corrected intestinal output. The pump input was measured at the end of each experiment and was given by the slope of the regression line (Goldstein, 1964) between time and cumulative weights of six five-minute collection periods.

The intestinal output for each five-minute period had to be calculated from the weight of the intestinal effluent and its concentration of polyethylene glycol because the volume capacity of a living intestinal segment is inconstant.

For an ideal nonabsorbable marker, quantity infused into segment $=$ quantity in effluent + quantity retained in segment

$$
\mathrm{C}_{\text {in }} \cdot \mathrm{V}_{\text {in }}=\mathrm{C}_{\text {out }} \cdot \mathrm{V}_{\text {out }}+\mathrm{C}_{\text {segment }} \cdot \Delta \mathrm{V}
$$

where $\mathrm{C}$ is the concentration of the marker, $\mathrm{V}$ is volume, $\Delta \mathrm{V}$ is the change in capacity of the segment. $\mathrm{C}_{\text {segment }}$ is assumed to be $\left(\mathrm{C}_{\text {in }}+\mathrm{C}_{\text {out }}\right) \div 2$. The change in capacity of the segment is

$$
\frac{2\left(C_{\text {in }} \cdot V_{\text {in }}-C_{\text {out }} \cdot V_{\text {out }}\right)}{C_{\text {in }}+C_{\text {out }}}
$$

and the corrected output $=$ weight of effluent $+\Delta \mathrm{V}$.

The regression line relating time and the cumulative 
corrected intestinal output was calculated. The slopes of the line from the control period and from the test period were compared with each other and with the slope of the regression line of the pump input.

Whether steady state conditions were obtained was decided by comparing the constancy of intestinal outputs with pump input. The standard deviation of a pump input line whose slope was 0.5 was about $0.001 \mathrm{mg} \mathrm{min}^{-1}$. About $20 \%$ of our experiments were rejected because the corrected intestinal output from either control or test period was in an unsteady state with respect to the pump input; that is, the estimates of error variance for the three regression lines were significantly different $(P<0.05)$.

Oxalate absorption was calculated from the volume infused into an intestinal segment during $30 \mathrm{~min}$, the concentration of ${ }^{14} \mathrm{C}$ in the infusion, the corrected volume of the intestinal effluent over $30 \mathrm{~min}$, and the concentration of ${ }^{14} \mathrm{C}$ in the intestinal effluent.

\section{Results}

\section{JEJUNUM (TABLE I)}

Absorption of water and oxalate was constant over the duration of the experiment when buffer was infused throughout.

Taurocholate, 10 mMolar, depressed absorption of both water and oxalate; absorption was not depressed further by $\mathrm{Ca}^{++}$or linoleic acid. Water transport and oxalate absorption were linearly related in these experiments $(r=0.6 ; P<0.001)$ : oxalate absorption, $\mathrm{m} \mu$ moles $\min ^{-1} \mathrm{~g}^{-1},=35+0 \cdot 2$ (water absorption, $\mathrm{mg} \mathrm{min}^{-1} \mathrm{~g}^{-1}$ ).

\section{ILEUM (TABLE II)}

There was no diminution in the absorption of water and oxalate when buffer was infused throughout an experiment. Taurocholate, $10 \mathrm{mMolar}$, had no effect on water absorption, which is consistent with a previous observation (Saunders, 1975).

Linoleic acid, 2 mMolar, depressed the absorption

\begin{tabular}{|c|c|c|c|c|c|c|}
\hline \multirow[t]{2}{*}{ Test Infusion } & \multicolumn{3}{|c|}{ Net $\mathrm{H}_{2} \mathrm{O}$ Transport } & \multicolumn{3}{|c|}{ Net Oxalate Transport } \\
\hline & $\begin{array}{l}\text { Control } \\
\left(\mathrm{mg} \mathrm{min}^{-1} \mathrm{~g}^{-1}\right)\end{array}$ & Test & $\begin{array}{l}\Delta \\
(\%)\end{array}$ & $\begin{array}{l}\text { Control } \\
\left(m \mu m o l e s \text { min }^{-1}\right.\end{array}$ & $\begin{array}{l}\text { Test } \\
\left.\mathrm{g}^{-1}\right)\end{array}$ & $\begin{array}{l}\Delta \\
(\%)\end{array}$ \\
\hline Buffer (6) & $203 \pm 8$ & $208 \pm 23$ & $3 \pm 10$ & $56 \pm 3$ & $53 \pm 5$ & $-5 \pm 6$ \\
\hline Taurocholate, $10 \mathrm{mM}$ (7) & $172 \pm 18$ & $102 \pm 20$ & $-42 \pm 9^{2}$ & $57 \pm 4$ & $48 \pm 5$ & $-17 \pm 5^{2}$ \\
\hline $\begin{array}{l}\text { Taurocholate, } 10 \mathrm{mM}(8) \\
\mathrm{CaCl}_{2}, 1 \mathrm{mM}\end{array}$ & $214 \pm 18$ & $77 \pm 11$ & $-52 \pm 8^{2}$ & $89 \pm 7$ & $70 \pm 6$ & $-20 \pm 7^{2}$ \\
\hline $\begin{array}{l}\text { Taurocholate, } 10 \mathrm{mM}(6) \\
\text { Linoleate, } 2 \mathrm{mM}\end{array}$ & $168 \pm 9$ & $113 \pm 8$ & $-32 \pm 4^{2}$ & $66 \pm 3$ & $43 \pm 5$ & $-34 \pm 7^{2}$ \\
\hline $\begin{array}{l}\text { Taurocholate, } 10 \mathrm{mM}(6) \\
\text { Linoleate, } 2 \mathrm{mM} \\
\mathrm{CaCl}_{2}, 1 \mathrm{mM}\end{array}$ & $188 \pm 11$ & $87 \pm 14$ & $-52 \pm 9^{2}$ & $87 \pm 5$ & $56 \pm 6$ & $-35 \pm 8^{8}$ \\
\hline
\end{tabular}

Table I Water and oxalate absorption in the jejunum ${ }^{1}$

${ }^{1}$ Buffer was infused during an initial control period. The values are means \pm SEM with (number of experiments).

'Significantly different from zero change, $P<0.05$, paired comparisons.

\begin{tabular}{|c|c|c|c|c|c|c|}
\hline \multirow{3}{*}{$\begin{array}{l}\text { Ĩest Infusion } \\
\text { Buffer (7) }\end{array}$} & \multicolumn{3}{|c|}{$\mathrm{Net} \mathrm{H}_{2} \mathrm{O}$ Transport } & \multicolumn{3}{|c|}{ Net Oxalate Transport } \\
\hline & \multirow{2}{*}{$\begin{array}{l}\begin{array}{l}\text { Control } \\
(m g \text { min }\end{array} \\
197 \pm 17\end{array}$} & \multirow{2}{*}{$\begin{array}{l}\text { Test } \\
166 \pm 17\end{array}$} & \multirow{2}{*}{$\begin{array}{l}\begin{array}{l}\Delta \\
(\%)\end{array} \\
-13 \pm 11\end{array}$} & \multicolumn{2}{|c|}{$\begin{array}{ll}\text { Control } & \text { Test } \\
\left(\mathrm{m \mu moles} \mathrm{min}^{-1} \mathrm{~g}^{-1}\right)\end{array}$} & \multirow{2}{*}{$\begin{array}{l}\Delta \\
(\%) \\
-5 \pm 12\end{array}$} \\
\hline & & & & $68 \pm 6$ & $61 \pm 4$ & \\
\hline Taurocholate, $10 \mathrm{mM}$ (7) & $206 \pm 23$ & $203 \pm 18$ & $3 \pm 10$ & $91 \pm 6$ & $85 \pm 10$ & $6 \pm 7$ \\
\hline $\begin{array}{l}\text { Taurocholate, } 10 \mathrm{mM}(6) \\
\mathrm{CaCl}_{2} 1 \mathrm{mM}\end{array}$ & $220 \pm 26$ & $267 \pm 22$ & $25 \pm 9$ & $119 \pm 11$ & $107 \pm 19$ & $8 \pm 8$ \\
\hline $\begin{array}{l}\text { Taurocholate, } 10 \mathrm{mM}(6) \\
\text { Linoleate, } 2 \mathrm{mM}\end{array}$ & $199 \pm 20$ & $146 \pm 18$ & $-24 \pm 8^{2}$ & $60 \pm 6$ & $37 \pm 7$ & $-36 \pm 11^{2}$ \\
\hline $\begin{array}{l}\text { Taurocholate, } 10 \mathrm{mM} \text { (6) } \\
\text { Linoleate, } 2 \mathrm{mM} \\
\mathrm{CaCl}_{2} 1 \mathrm{mM}\end{array}$ & $249 \pm 17$ & $257 \pm 19$ & $4 \pm 5$ & $118 \pm 8$ & $109 \pm 10$ & $-7 \pm 7$ \\
\hline
\end{tabular}

Table II Water and oxalate absorption in the ileum ${ }^{1}$

${ }^{1}$ Buffer was infused during an initial control period. The values are means \pm SEM with (number of experiments).

significantly different from zero change, $\mathrm{P}<0.05$, paired comparisons. 


\begin{tabular}{|c|c|c|c|c|c|c|}
\hline \multirow[t]{2}{*}{ Test Infusion } & \multicolumn{3}{|c|}{$\mathrm{Net} \mathrm{H}_{2} \mathrm{O}$ Transport } & \multicolumn{3}{|c|}{ Net Oxalate Transport } \\
\hline & 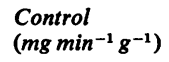 & Test & $\begin{array}{l}\Delta \\
(\%)\end{array}$ & $\begin{array}{l}\text { Control } \\
\left(m \mu m o l e s \text { min }^{-1}\right.\end{array}$ & $\begin{array}{l}\text { Test } \\
\left.g^{-1}\right)\end{array}$ & $\begin{array}{l}\Delta \\
(\%)\end{array}$ \\
\hline Buffer (7) & $220 \pm 8$ & $229 \pm 18$ & $-5 \pm 9$ & $34 \pm 5$ & $33 \pm 4$ & $-1 \pm 2$ \\
\hline Taurocholate, $10 \mathrm{mM}(8)$ & $261 \pm 19$ & $185 \pm 16$ & $-29 \pm 4^{2}$ & $50 \pm 18$ & $17 \pm 4$ & $-54 \pm 12^{2}$ \\
\hline $\begin{array}{l}\text { Taurocholate, } 10 \mathrm{mM}(8) \\
\mathrm{CaCl}_{2}, 1 \mathrm{mM}\end{array}$ & $187 \pm 16$ & $200 \pm 13$ & $9 \pm 6$ & $19 \pm 4$ & $27 \pm 4$ & $42 \pm 19$ \\
\hline $\begin{array}{l}\text { Taurocholate, } 10 \mathrm{mM}(8) \\
\text { Linoleate, } 2 \mathrm{mM}\end{array}$ & $267 \pm 19$ & $112 \pm 20$ & $-58 \pm 7^{2}$ & $32 \pm 6$ & $45 \pm 6$ & $60 \pm 18^{2}$ \\
\hline $\begin{array}{l}\text { Taurocholate, } 10 \mathrm{mM}(10) \\
\text { Linoleate, } 2 \mathrm{mM} \\
\mathrm{CaCl}_{2}, 1 \mathrm{mM}\end{array}$ & $238 \pm 20$ & $185 \pm 25$ & $-23 \pm 7^{2}$ & $41 \pm 5$ & $14 \pm 5$ & $-67 \pm 11^{2}$ \\
\hline
\end{tabular}

Table III Water and oxalate absorption in the colon ${ }^{1}$

${ }^{1}$ Buffer was infused during an initial control period. The values are means \pm SEM with (number of experiments). 'Significantly different from zero change, $P<0.05$, paired comparisons.

\begin{tabular}{|c|c|c|c|c|c|c|}
\hline \multirow[t]{2}{*}{ Test Infusion } & \multicolumn{3}{|c|}{ Net $\mathrm{H}_{2} \mathrm{O}$ Transport } & \multicolumn{3}{|c|}{ Net Oxalate Transport } \\
\hline & 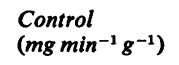 & Test & $\begin{array}{l}\Delta \\
(\%)\end{array}$ & $\begin{array}{l}\text { Control } \\
\text { (mumoles } \text { min }^{-1}\end{array}$ & $\begin{array}{l}\text { Test } \\
\left.\mathrm{g}^{-1}\right)\end{array}$ & $\begin{array}{l}\Delta \\
(\%)\end{array}$ \\
\hline $\mathrm{CaCl}_{2}, 1 \mathrm{mM}(8)$ & $222 \pm 17$ & $222 \pm 13$ & $2 \pm 5$ & $19 \pm 2$ & $24 \pm 2$ & $0 \pm 7$ \\
\hline Linoleate, $2 \mathrm{mM}$ (10) & $236 \pm 14$ & $117 \pm 20$ & $-49 \pm 8^{2}$ & $29 \pm 4$ & $27 \pm 4$ & $5 \pm 16$ \\
\hline $\begin{array}{l}\text { Linoleate, } 2 \mathrm{mM} \text { (12) } \\
\mathrm{CaCl}_{2}, 1 \mathrm{mM}\end{array}$ & $242 \pm 17$ & $232 \pm 13$ & $-2 \pm 6$ & $28 \pm 4$ & $23 \pm 3$ & $-6 \pm 7$ \\
\hline
\end{tabular}

Table IV Water and oxalate absorption from $2.5 \mathrm{mM}$ taurocholate in the colon ${ }^{1}$

${ }^{1}$ Taurocholate, $2.5 \mathrm{mM}$, was infused during control and test periods. The values are means $\pm \mathrm{SEM}$ with (number of experiments).

'Significantly different from zero change, $P<0.05$, paired comparisons.

of both oxalate and water. Oxalate absorption and water absorption were linearly related in this experiment: $y=6+0.2 x(\mathrm{r}=0.7 ; \mathrm{P}<0.05)$.

\section{COLON (TABLES III AND IV)}

The absorption of water and oxalate was constant when buffer was infused throughout an experiment.

Mean oxalate absorption in control periods in the colon, $37 \mathrm{~m} \mu$ moles $\mathrm{min}^{-1} \mathrm{~g}^{-1}$, was lower than in the ileum, $68 \mathrm{~m} \mu$ moles $\mathrm{min}^{-1} \mathrm{~g}^{-1}$, although net water transport during control periods was similar in both regions.

The results of infusing $10 \mathrm{mMolar}$ taurocholate during test periods are given in table III. Taurocholate, 10 mMolar, depressed absorption of both oxalate and water. This depression was negated by calcium.

Oxalate absorption was linearly related to net water transport: $y=-28+0.3 x(\mathrm{r}=0.6$; $P<0.001)$ except when linoleic acid was present with $10 \mathrm{mMolar}$ taurocholate. In this experiment, oxalate absorption was dissociated from net water transport $(r=-0 \cdot 1)$. Linoleic acid caused a greater depression of net water transport than did infusions containing only taurocholate $(t=3 \cdot 68$,
$P<0.05$ ), while it enhanced the absorption of oxalate. Calcium negated the inhibitory effort of linoleic acid on water transport and the stimulative effect of linoleic acid on oxalate absorption.

The results of infusing a lower concentration of taurocholate during control and test periods are given in table IV. Net water transport and oxalate absorption were unaffected by calcium or by linoleic acid with calcium; in these experiments oxalate absorption was linearly related to net water transport: $y=-2+0.1 x(\mathrm{r}=0.5 ; \mathrm{P}<0.005)$. Linoleic acid without calcium depressed net water transport, but it did not inhibit oxalate absorption; in this experiment, oxalate absorption was dissociated from net water transport $(r=0.4 ; P<0 \cdot 1)$.

\section{Discussion}

This study indicates that regional differences in oxalate absorption exist in rat intestine. Because oxalate is passively absorbed by intestinal mucosa (Binder, 1974), it was not surprising to find that manipulations which depressed net water transport in jejunum or in ileum also inhibited oxalate absorption. Disparate effects on water and on 
oxalate absorption were demonstrated in the colon, however.

Data from in-vitro and in-vivo experiments led us to expect the following results from infusing rat colon: $\mathrm{Ca}^{++}$would inhibit oxalate absorption while added long-chain fatty acid would remove this inhibition by precipitating calcium (Binder, 1974). Fatty acid without calcium, however, might depress net water transport (Ammon and Phillips, 1974; Bright-Asare and Binder, 1973) resulting in a concomitant depression of oxalate absorption. Actually, taurocholate seemed to prevent the precipitation of calcium oxalate; infusions of $\mathrm{Ca}^{++}$, and oxalate were optically clear, and oxalate absorption was uninhibited by $\mathrm{Ca}^{++}$. Linoleate did inhibit net water transport, but, paradoxically, it facilitated oxalate absorption from the colon. $\mathrm{Ca}^{++}$ negated these effects of long-chain fatty acid by, presumably, forming insoluble calcium linoleate; linoleate infusions which contained $\mathrm{Ca}^{++}$were opalescent.

Our data suggest that excessive luminal concentrations of bile salts and long-chain fatty acids may enhance oxalate absorption from a normal colon.

How relevant are these observations to understanding the hyperoxaluria of human intestinal disease? In the first place, the colon is responsible for a significant proportion of the normal intestinal absorption of oxalate in man (Earnest, 1974, personal communication) and in primates (Chadwick, Elias, Modha, and Dowling, 1973), and it is necessary for the excessive absorption of oxalate in patients with entelic hyperoxaluria. Patients who have had an extensive ileal resection and colectomy do not develop hyperoxaluria even with a diet high in oxalate (Earnest et al, 1974). Enteric hyperoxaluria has not been described in ileostomy patients, who have a high incidence of renal calculi; their stones are of urate rather than of oxalate (Bennett and Jepson, 1966).

In the second place, there appears to be a positive correlation between faecal fat and urinary oxalate (Earnest et al, 1974; Stauffer et al, 1974; Andersson and Jagenburg, 1974; McDonald et al, 1975). Furthermore, increasing the amount of fat in an otherwise constant diet enhanced urinary oxalate excretion in patients with enteric hyperoxaluria (Earnest et al, 1974).

In the third place, the human colon may be presented with high concentrations of bile salts and fatty acids in small intestinal disease. The small amount of bile salts in normal faeces is bound to solid material (Norman, 1964; Findlay, Eastwood, and Mitchell, 1973). The concentration of bile salts can be 30 mMolar in the solid residue and 13 mMolar in the supernatant portion of faeces from patients with ileal resection or disease (Mitchell, Findlay, Prescott, Eastwood, and Horn, 1973; Hofmann and Poley, 1972). Fatty acids in the aqueous phase would be a $2 \mathrm{mMolar}$ if about $0.6 \mathrm{~g}$ of long-chain fatty acid could be solubilized by a litre of faecal water.

Finally, calcium, added to the diet, can decrease urinary oxalate excretion in patients with enteric hyperoxaluria (Earnest et al, 1974; Stauffer et al, 1974) although this therapy is not always successful (Chadwick, Modha, and Dowling, 1974). Oxalate excretion is inversely related to the dietary intake of calcium in normal man (Zarembski and Hodgkinson, 1969). The combination of low dietary calcium and high dietary oxalate produces the highest urinary oxalate excretion (Marshall, Cochran, and Hodgkinson, 1972).

These combined observations suggest that small intestinal disease may lead to enhanced oxalate absorption from the colon by altering the composition of colonic contents.

This project was supported by research grant AM 16059 from the National Institutes of Health, by a research career development award AM 35150 from the National Institute of Arthritis and Metabolic Diseases, and by the Postdoctoral Research Training Program in Gastroenterology 5 T01 AM 05099 from the National Institute of Arthritis and Metabolic Diseases. The technique of measuring net water transport was devised in the Oxford laboratory of Dr D. S. Parsons (Saunders, 1975).

\section{References}

Admirand, W. H., Earnest, D. L., and Williams, H. E. (1971). Hyperoxaluria and bowel disease. Trans. Ass. Amer. Phycns, 84, 307-312.

Ammon, H. V., and Phillips, S. F. (1974). Inhibition of ileal water absorption by intraluminal fatty acids. J. clin. Invest., 53,
$205-210$.

Andersson, H., and Jagenburg, R. (1974). Fat-reduced diet in the treatment of hyperoxaluria in patients with ileopathy. Gut, 15, 360-366.

Archer, H. E., Dormer, A. E., Scowen, E. F., and Watts, R. W. E (1957). Studies on the urinary excretion of oxalate by normal subjects. Clin. Sci., 16, 405-411.

Bennett, R. C., and Jepson, R. P. (1966). Uric acid stone formation following ileostomy. Aust. N.Z. J. Surg., 36, 153-158.

Binder, H. J. (1974). Intestinal oxalate absorption. Gastroenterology, 67, 441-446.

Bright-Asare, P., and Binder, H. J. (1973). Stimulation of colonic secretion of water and electrolytes by hydroxy fatty acids. Gastroenterology, 64, 81-88.

Carter, G. W., and Van Dyke, K. (1971). A superior counting solution for water-soluble tritiated compounds. Clin. Chem., 17, 576-580.

Chadwick, V. S., Modha, K., and Dowling, R. H. (1973). Mechanism of hyperoxaluria in patients with ileal dysfunction. New Engl. J. Med., 289, 172-176.

Chadwick, V. S., Elias, E., Modha, K., and Dowling, R. H. (1973). Pathogenesis and treatment of secondary hyperoxaluria in patients with ileal resection. (Abstr.) Quart. J. Med., 42, 826

Chadwick, V. S., Modha, K., and Dowling, R. H. (1974). Letter to the Editor. New Engl. J. Med., 290, 108. 
Dickstein, S. S., and Frame, B. (1973). Urinary tract calculi after intestinal shunt operations for the treatment of obesity. Surg. Gynec. Obstet., 136, 257-260.

Dowling, R. H., Rose, G. A., and Sutor, D. J. (1971). Hyperoxaluria and re:al calculi in ileal disease. Lancet, 1, 1103-1106.

Earnest, D. L., Johnson, G., Williams, H. E., and Admirand, W. (1974). Hyperoxaluria in patients with ileal resection: An abnormality in dietary oxalate absorption. Gastroenterology, 66, 1114-1122.

Findlay, J. M., Eastwood, M. A., and Mitchell, W. D. (1973). The physical state of bile acids in the diarrhoeal stool of ileal dysfunction. Gut, 14, 319-323.

Goldstein, A. (1964). Biostatistics, pp. 136-146. MacMillan, London and New York.

Hofmann, A. F., and Poley, J. R. (1972). Role of bile acid malabsorption in pathogenesis of diarrhea and steatorrhea in patients with ileal resection. Gastroenterology, 62, 918-934.

Marshall, R. W., Cochran, M., and Hodgkinson, A. (1972). Relationships between calcium and oxalic acid intake in the diet and their excretion in the urine of normal and renal-stone-forming subjects. Clin. Sci., 43, 91-99.

McDonald, G. B., Earnest, D. L., and Admirand, W. H. (1975). Hyperoxaluria correlates with steatorrhea in patients with celiac sprue. (Abstr.) Gastroenterology, 68, 949.

Mitchell, W. D., Findlay, J. M., Prescott, R. J., Eastwood, M. A., and Horn, D. B. (1973). Bile acids in the diarrhoea of ileal resection. Gut, 14, 348-353.
Norman, A. (1955). Preparation of conjugated bile acids using mixed carboxylic acid anhydrides. Arkiv. für Kemi, 8, 331-342.

Norman, A. (1964). Faecal excretion products of cholic acid in man. Brit. J. Nutr., 18, 173-186.

O'Leary, J. P., Thomas, W. C., and Woodward, E. R. (1974). Urinary tract stone after small bowel bypass for morbid obesity. Amer. J. Surg., 127, 142-147.

Saunders, D. R. (1975). Regional differences in the effect of bile salts on absorption by rat small intestine in vivo. J. Physiol. (Lond.), in press.

Saunders, D. R., Hedges, J. R., Sillery, J., Esther, L., Matsumura, K., and Rubin, C. E. (1975). Morphological and functional effects of bile salts on rat colon. Gastroenterology, 68, 1236-1245.

Smith, L. H., Fromm, H., and Hofmann, A. F. (1972). Acquired hyperoxaluria, nephrolithiasis, and intestinal disease. New Engl. J. Med., 286, 1371-1375.

Stauffer, J. Q., Humphreys, M. H., and Weir, G. J. (1973). Acquired hyperoxaluria with regional enteritis after ileal resection: Role of dietary oxalate. Ann. intern. Med., 79, 383-391.

Stauffer, J. Q., Stewart, R. J., and Bertrand, G. (1974). Acquired hyperoxaluria: Relationship to dietary calcium content and severity of steatorrhea. (Abstr.) Gastroenterology, 66, 783.

Zarembski, P. M., and Hodgkinson, A. (1962). The oxalic acid content of English diets. Brit. J. Nutr., 16, 627-634.

Zarembski, P. M., and Hodgkinson, A. (1969). Some factors influencing the urinary excretion of oxalic acid in man. Clin. Chim. Acta, 25, 1-10. 